\title{
振動による等価動摩擦係数の挙動* 一椿円振動場合一
}

\author{
石川憲一** 横 山恭 男*** \\ Behavior of Effective Kinetic Friction by Elliptical Vibration \\ Ken-ichi IshIKawa, Yasuo Yokoyama
}

When a solid body slides on a vibrated surface, effective friction is apparently reduced. This paper treats such a case as a solid body sliding on a surface vibrated elliptically, though in the previous paper it is vibrated rectilinearly. If the velocity ratio $V$ (the velocity of the solid body $\dot{X}$ to the vibration velocity $A \omega$ ) is nearly zero, then it is shown after analytical calculations that the coefficient of effective kinetic friction, $\mu_{k}^{\prime}$ gradually approaches a value that is not zero, when the frictional surface is vibrated elliptically with a component in the normal direction. Under certain conditions, however, $\mu_{k}^{\prime}$ becomes an equivalent negative value; and therefore, in the present paper it should be called "the negative coefficient of the effective kinetic friction". When it is elliptically vibrated without a component in the normal direction, $\mu_{k}^{\prime}$ gradually approaches zero and is not negative. However, equivalent effects on friction are larger than in the case of rectilinear vibration. Thus, there are some substantial differences between them. These theoretical results have also been confirmed by experimental studies. The analytical calculation in this paper is to be applied to the effects of vibration on friction as a general theory.

\section{1. 緒言}

従来, 摩擦之振動とに関連のある諸問題はいままで多 くの研究者によって研究・考察されてきており, それら は次のよらに分類されるものと考えられる.

i ）摩擦の影響を受ける振動

ii）摩擦によって生ずる振動

iii）振動の影響を受ける摩擦

iv）摩擦と振動を要因とする現象

すなわち，i）の場合は固体摩擦の存在によって振動の 挙動がどのように影響を受けるかということについてで あって, 古くはHartog 以来数多く取扱われてきている 問題であるが，非線形問題のためいまだ必ずしも明快な 厳密解は得られていないようである1)2). またii)の場合 はいわゆる摩擦振動3)であって摩擦特性の負特性によっ て生ずる自励振動として考察することができ, クラッチ やブレーキのきしみや工作機械のしゅら動部分のスティ ックスリップ等を例として挙げることができる.

次に, iii) の場合はそれらとは逆に, 固体摩擦に及ぼ す振動の効果4)5）を取扱ったものである，なお，iv）の

* 原稿受付 昭和 52 年 3 月 28 日. 昭和 44 年度精機学会 春季大会学術講演会（昭和 44 年 4 月 4 日）にて発表.

** 正 会員 金沢工業大学 (金沢市南郊野々市町扇が丘 7 番 1 号)

*** 正 会 員 金沢大学工学部 (金沢市小立野 2-40-20)
場合は摩擦と振動とがそれぞれ独立に重要な因子となっ ている現象をいい,例党ば振動輸送6)や振動による摩耗7) 等が挙げられる.

筆者らは上述 iii) の場合の一つとして別報5)に拈いて 直線振動が作用する場合の等価的な摩擦の減少効果とク 一ロン摩擦特性の線形化について報告した. 棈円振動が 作用する場合も見か忴上動摩擦は減少するが, 直線振動 が作用する場合と比較して, 例えば負の等価動摩擦係数 というようなかなり本質的に異なった現象がみられる.

従って, 本論文ではさらに一般の場合として直線振動 をも包括する棈円振動が作用する場合の等価的な動摩擦 の挙動について報告する.

\section{2. 作用する振動と若干の仮定}

各座標軸については図 1 に示すように, 物体のすべり 方向を $X$ 軸, 摩擦面に垂直な方向を $Z$ 軸, $X, Z$ 各軸に 直角な方向を $Y$ 軸とする.

いま, $a, b, c$ を各軸方向の変位振幅, $\omega$ を円振動数, $\delta_{y}, \delta_{z}$ を $X$ 軸方向の振動に対する $Y$ および $Z$ 軸方向の 振動の位相角とし, 極座標に準じて表せば, 各振動変位 成分はそれぞれ

$$
\left.\begin{array}{l}
x=A \sin \gamma \cos \phi \sin \omega t \\
y=A \sin \gamma \sin \phi \sin \left(\omega t+\delta_{y}\right) \\
z=A \cos \gamma \sin \left(\omega t+\delta_{z}\right)
\end{array}\right\}
$$




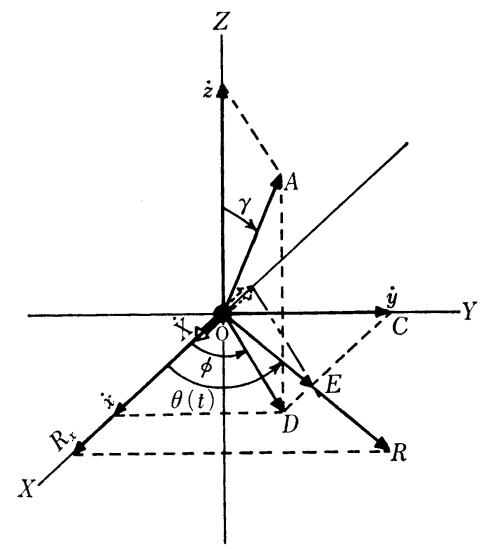

図 1 振動の方向と動摩擦力の成分

で表される.ここで, $A=\sqrt{a^{2}+b^{2}+c^{2}}, \phi=\tan ^{-1}(b / a):$ $X-Y$ 平面上での方向角, $\left.\gamma=\tan ^{-1} \sqrt{a^{2}+b^{2}} / c\right): Z$ 軸か らの方向角.

なお，解析に当たって速度成分が重要な要素となるの で, 図 1 は各速度成分について表してある，また，位相 角はー $\pi \leqq \delta_{y} \leqq \pi,-\pi \leqq \delta_{z} \leqq \pi$ の範囲について取扱らが, $\delta_{y}, \delta_{z}$ がともに0 あるいは土 0 のときは㨁線振動，一般に は棈円振動を表す，その結果，振動の方向は振動の対称 性を考えれば, $0<\gamma \leqq \pi / 2,0 \leqq \phi \leqq \pi / 2$ の範囲について 考察すれば十分である.

ところで，作用する棈円振動は $\gamma, \phi, \delta_{y}, \delta_{z}$ の 各パラメ 一タに依存して種々の形態となることから，本稿では取 扱いの都合上表 1 のよらに分類することにする.

次に, このような楕円振動の影響を受ける動摩擦の挙

表 1 楕円振動の形態

\begin{tabular}{|c|c|c|c|c|c|c|c|c|}
\hline & A & B & $\mathrm{C}$ & $\mathrm{D}$ & $\mathrm{E}$ & $\mathrm{F}$ & G & $\mathrm{H}$ \\
\hline$x$ & 0 & ○ & 0 & 0 & 0 & $x$ & 0 & \\
\hline$y$ & 0 & 0 & 0 & $\bigcirc$ & $x$ & 0 & 0 & \\
\hline$z$ & 0 & 0 & 0 & 0 & 0 & 0 & $x$ & \\
\hline$\delta_{y}$ & 0 & 0 & 0 & $x$ & $x$ & 0 & 0 & $x$ \\
\hline$\delta_{z}$ & $*$ & $* *$ & $* * *$ & O & 0 & 0 & $x$ & $x$ \\
\hline 振動の形態 & 一般 & $\beta$ 平面 & $\alpha$ 平面 & $\phi$ 平面 & $\begin{array}{l}X-Z \\
\text { 平面 }\end{array}$ & $\begin{array}{l}Y-Z \\
\text { 平面 }\end{array}$ & $\begin{array}{l}X-Y \\
\text { 平面 }\end{array}$ & 直線 \\
\hline $\begin{array}{l}\text { 負の } \mu k^{\prime} \text { そな } \\
\text { 万る条件 }\end{array}$ & 0 & $\bigcirc$ & 0 & 0 & 0 & $x$ & $x$ & $x$ \\
\hline
\end{tabular}

○一あり, $\times \cdots な し$

直線振動の場合の詳細は省略してある.

* $\delta_{z} \neq \delta_{y}, \quad \delta_{z} \neq \delta_{y} \pm \pi$

$* * \quad \delta_{z}=\delta_{y}, \quad \delta_{z}=\delta_{y} \pm \pi$

$\beta: Y-Z$ 平面内において $Z$ 軸からの方向角. ただし， $\beta= \pm \tan ^{-1}(\tan \gamma \cdot \sin \phi)$

複号は $\delta_{z}=\delta_{y}$ のとき $(+), \delta_{z}=\delta_{y} \pm \pi$ のとき $(-)$

*** $\quad \delta_{z}=0, \quad \delta_{z}= \pm \pi$

$\alpha: X-Z$ 平面内において $Z$ 軸からの方向角. ただし, $\alpha= \pm \tan ^{-1}(\tan \gamma \cdot \cos \phi)$

複号は $\delta_{z}=0$ のとき $(+), \delta_{z}= \pm \pi$ のとき $($ 一)

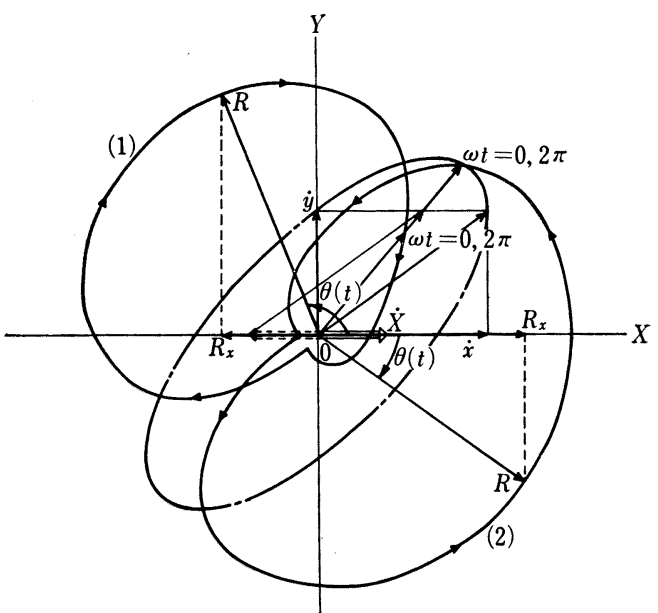

$\gamma=\pi / 6, \quad \phi=\pi / 4, \quad A=1, \quad V=\sqrt{ } \bar{Z} / 5$

(1): $\delta_{y}=\pi / 4, \delta_{z}=0$ ( $\alpha$ 平面), (2): $\delta_{y}=\delta_{z}=\pi / 4$ ( $\beta$ 平面) 一 点鎖線：棈円振動の速度ベクトルの軌跡, 実線：すべり面上の 動摩擦力ベクトルの軌跡

図 2 振動速度と動摩擦力との関係（ $\alpha$ および $\beta$ 平面内の楕円 振動の場合)

動を解析するにあたって，物体の運動に関し問題点を簡 単にするために若干の仮定をおく必要がある。すなお ち, 動摩擦力はアモントン・クーロンの法則に従い, 作 用する振動は微小で振動の影響によって生ずる交番摩擦 力に比べて物体の応答は無視できる程小さい*と考える. また，等価的な摩擦力は振動の性質や方向にかかわらず すべり方向についてのみ考察し，かつ摩擦の本質上物体 はすべり面上に拘束され，分離跳躍は伴わないものとす る.

\section{3. すべり面上の動摩擦力}

図 1 に示すように，任意の時間におけるすべり 面の振動速度を $\overrightarrow{\mathrm{OA}}$ で表すと， $X-Y$ 平面上の成 分は $\overrightarrow{\mathrm{OD}}$ となる.このとき, 物体は速度 $\vec{X} て ゙ X$ 軸 方向にすべり運動をするから，その相対摩擦速度 $\overrightarrow{\mathrm{OE}}$ は $\overrightarrow{\mathrm{OD}}$ と $\overrightarrow{\dot{X}}$ とのベクトル差として求められ, 相対摩擦速度成分 $V_{x}, V_{y}$ は

$$
\left.\begin{array}{l}
V_{x}=A \omega \sin \gamma \cos \phi \cos \omega t-\dot{X} \\
V_{y}=A \omega \sin \gamma \sin \phi \cos \left(\omega t+\delta_{y}\right)
\end{array}\right\}
$$

\section{で表される.}

したがって, 時刻 $t$ における $X$ 軸方向と $\overrightarrow{\mathrm{OE}}$ と のなす角を $\theta(t)$ で表せば， $\theta(t)$ は

$$
\theta(t)=\tan ^{-1}\left(V_{y} / V_{x}\right)
$$

* 物体の応答が無視できない場合は別報 ${ }^{6)}$ に論じて ある。 


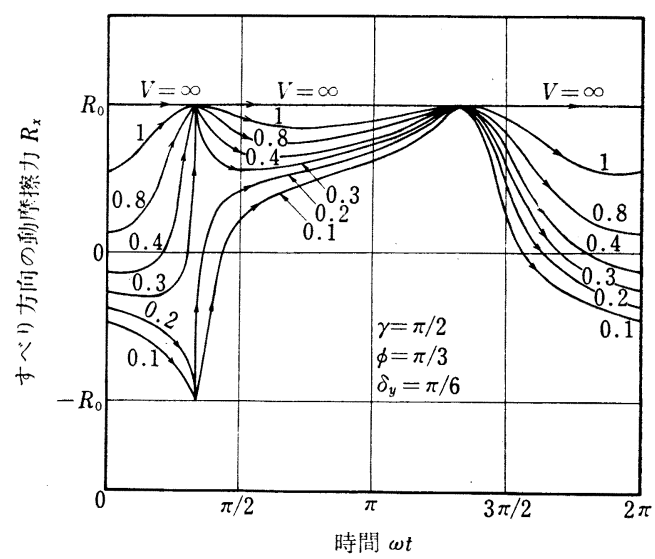

図 3 すべり方向の動摩擦力の 1 周期間の変動（ $X-Y$ 平面 内の楕円振動の場合）

$$
=\tan ^{-1}\left\{\frac{\sin \gamma \sin \phi \cos \left(\omega t+\delta_{y}\right)}{\sin \gamma \cos \phi \cos \omega t-V}\right\}
$$

となる、ここで， $V=\dot{X} / A \omega$ は速度比を表す．

このとき, 摩擦の性質よりすべり面上の摩擦力 $R$ は, $\theta(t)$ の方向作用する．振動が作用しない場合の真の動 摩擦力を $\mu_{k} m g\left(\mu_{k}\right.$ : 真の動摩擦係数, $m$ : 物体の質量, $g$ ：重力加速度）として法線方向の振動加速度による慣 性力の重畳を考慮すれば， $R$ は次のようになる.

$$
\begin{aligned}
R & =\mu_{k} m g+\mu_{k} m \ddot{z} \\
& =R_{0}\left\{1-\Lambda \cos \gamma \sin \left(\omega t+\delta_{z}\right)\right\}
\end{aligned}
$$

ここで, $R_{0}=\mu_{k} m g, \Lambda=A \omega^{2} / g$ (加速度比) を表す.

図 2 亿は， $\alpha$ 平面および $\beta$ 平面内の棈円振動が作用す る場合の動摩擦力ベクトルの軌跡 (1), (2) が示されてい るが，一般の棈円振動が作用する場合もその軌跡は類似

$$
R_{x}=R \cos \theta(t)
$$

$$
=\frac{R_{0}\left\{1-\Lambda \cos \gamma \sin \left(\omega t+\delta_{z}\right)\right\}(V-\sin \gamma \cos \phi \cos \omega t)}{\sqrt{(\sin \gamma \cos \phi \cos \omega t-V)^{2}+\left\{\sin \gamma \sin \phi \cos \left(\omega t+\delta_{y}\right)\right\}^{2}}}
$$

で表されるが， $R_{x}$ は振動の方向，大きさ，位相角に応 じてそれぞれ特有の変動を示す，そこで，楕円振動の影 響を受ける場合の $R_{x}$ につて若干例を示しながら説明 する.

図 3 には， $X-Y$ 平面内の棈円振動が作用する場合 の $R_{x}$ の振動 1 周期間にわたる変動が示されている． $R_{x}$ は 時間とともに変化するが， $R_{x}$ の正負の反転は $V$ が次式 を満たすときに生ずる.

$$
V<\cos \phi
$$

ところで，直線振動の場合には，時刻 $\pi / 2,3 \pi / 2$ に おいて振動速度がゼロとなるから, それらの時刻で $R_{x}=$ $R_{0}$ となる. しかしながら，棈円振動では時刻 $\pi / 2-\delta_{y}$ のとき， $R_{x}=R_{0}$ となる. そこで, $R_{x}=-R_{0}$ となる条

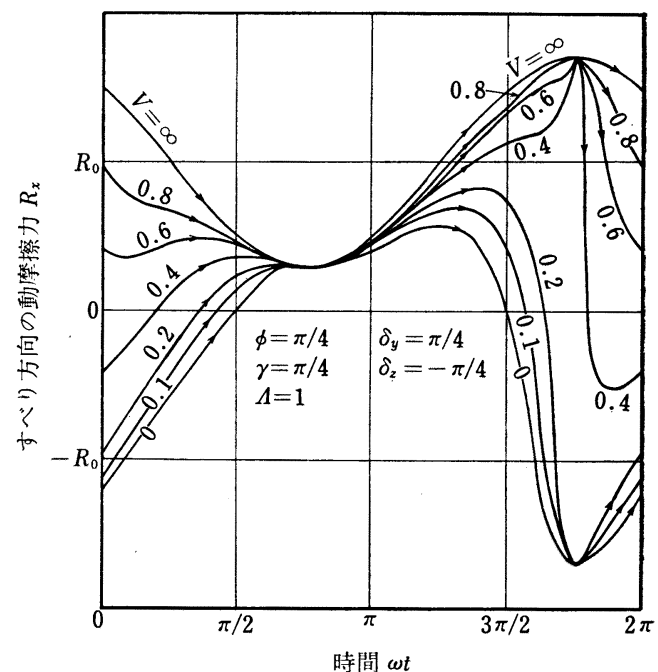

図 4 すべり方向の動摩擦力の 1 周期間の変動 $(\beta$ 平面内 の棈円振動の場合）

した挙動を示し，時間とともに変化する。しかしなが ら， $X-Y$ 平面内の棈円振動が作用する場合には，法線 方向成分を有しないから，動摩擦力ベクトルの軌跡は半 径 $R_{0}$ の円周上に沿って変動する.

\section{4. すべり方向の動摩擦力}

一般に，摩擦力は物体のすべり方向と反対方向に作用 することから，第 2 章の仮定に従い振動が作用する場合 も物体のすべり方向の動摩擦力 $R_{x}$ を取扱 ことにす る. その結果，すべり方向の動摩擦力 $R_{x}$ は，図 2 を参 照して

件は,

$$
V<\cos \left(\pi / 2-\delta_{y}\right) \cos \phi
$$

で求められ，図 3 の場合は， $V<0.25$ となると， $R_{x}=-R_{0}$ に達する.

図 4 亿は， $\beta$ 平面内の棈円振動が作用する場合におけ る $R_{x}$ の 1 周期間の変動が示されている.この場合は法線 方向の振動加速度の影響が現れるとともに位相角にも依 存して, 時刻 $\pi / 2-\delta_{y}$ のとき $R_{x}=R_{0}\left\{1-\Lambda \cos \gamma \cos \left(\delta_{z}\right.\right.$ $\left.\left.-\delta_{y}\right)\right\}$ となり, 時刻 $3 \pi / 2-\delta_{y}$ のとき, $R_{x}=R_{0}\{1+\Lambda$ $\left.\cos \gamma \cos \left(\delta_{z}-\delta_{y}\right)\right\}$, あるいは $R_{x}=-R_{0}\{1+\Lambda \cos \gamma \cos$ $\left.\left(\delta_{z}-\delta_{y}\right)\right\}$ になるが, $R_{x}=-R_{0}\left\{1+\Lambda \cos \gamma \cos \left(\delta_{z}-\delta_{y}\right)\right\}$ となる条件は

$$
V<\sin \gamma \cos \left(3 \pi / 2-\delta_{y}\right) \cos \phi
$$


で求められる. ところで，図 4 の場合は時刻 $3 \pi / 4$ で $R_{x}$ $\fallingdotseq 0.293 R_{0}$ となり, 時刻 $7 \pi / 4$ で $R_{x} \fallingdotseq 1.707 R_{0}$, また式 (8)より, $V<\sqrt{2} / 4 \fallingdotseq 0.354$ のとき， $R_{x} \fallingdotseq-1.707 R_{0}$ に 達する.

このように棈円振動と直線振動とでは， $R$ および $R_{x}$ の変動に関しかなりの相違点が存在することがわかる.

$$
\begin{aligned}
\frac{\bar{R}_{x}}{R_{0}} & =\frac{\mu_{k}^{\prime}}{\mu_{k}} \\
& =\frac{1}{2 \pi} \int_{0}^{2 \pi} \frac{\left\{1-\Lambda \cos \gamma \sin \left(\omega t+\delta_{z}\right)\right\}(V-\sin \gamma \cos \phi \cos \omega t)}{\sqrt{(\sin \gamma \cos \phi \cos \omega t-V)^{2}+\left\{\sin \gamma \sin \phi \cos \left(\omega t+\delta_{y}\right)\right\}^{2}}} \mathrm{~d}(\omega t)
\end{aligned}
$$

棈円振動が作用する場合には, 等価動摩擦係数の減少 に関して位相角の依存性が顕著であることから，まず位 相角の影響について考察することにする.

図 5 には， $X-Y$ 平面内の 楕円振動が作用する場合の 等価動摩擦係数の 減少と位相角 $\delta_{\boldsymbol{y}}$ の関係の 数值計算例 が示されている. この場合には摩擦低減効果の最も大き い位相角は $\delta_{y}= \pm \pi / 2$ のときで, 振動の方向は $\phi \rightarrow 0$ で あるが, 数值計算の結果より $0<\phi<\pi / 6$ では近似的に 相等しい.

図 6,7 には，法線方向成分を有する棈円振動が作用す る場合に拈ける等価動摩擦係数の減少と位相角との関係 の数値計算例が示されている. これらの結果を比較する と，条件によっては $\mu_{k}{ }^{\prime}$ はみかけ上負となることがわか る. 元来, 摩擦力は物体の運動を妨げる方向に働く受動 要素であるが, 振動の位相角に依存して物体の運動を助 ける方向に働く，いわゆる “負抵抗” の現象を呈するよ らになる.このことは一種の自励振動現象の原因にもな り得, 楕円振動が作用した場合摩擦を含む機器要素の動 作の安定性をそこなら原因にもなりらる. そして，この ような結果はたとえ直線振動や法線方向成分を有しない 棈円振動が作用しても， $V \rightarrow 0$ とともに $\mu_{k}^{\prime} \rightarrow 0$ となるこ

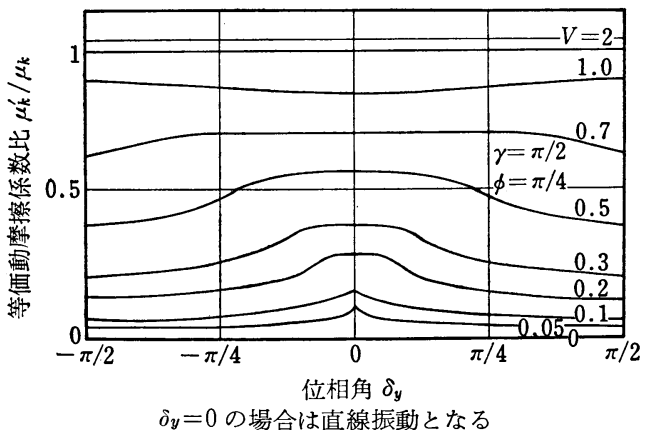

図 5 等価動摩擦係数の減少と位相角との関係 $(X-Y$ 平面 内の棈円振動の場合）

\section{5. 等価動摩擦係数 (力)}

棈円振動の影響を受ける $R_{x}$ は特徵のある周期的変動 を示すことがわかったが，等価的には時間について平均 した動摩擦力が物体に作用した場合と考えることができ る.したがって，その平均的な動摩擦力を等価動摩擦力 $\bar{R}_{x}$ (また， $\mu_{k}{ }^{\prime}$ ：等価動摩擦係数）と定義すれば，それら は次式で表される.

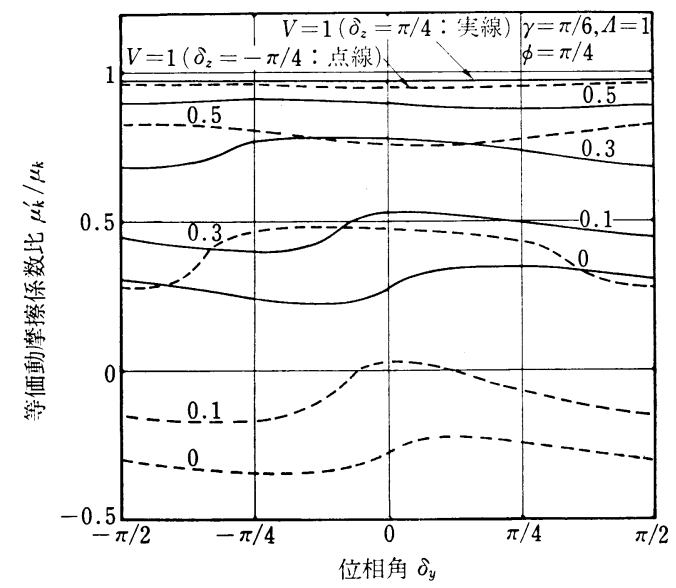

$\delta_{y}=0$ のとき $\phi$ 平面, $\delta_{y}=\delta_{z}(= \pm \pi / 4)$ のとき $\beta$ 平面

図 6 等価動摩擦係数の減少と位相角との関係（一般の 棈円振動の場合）

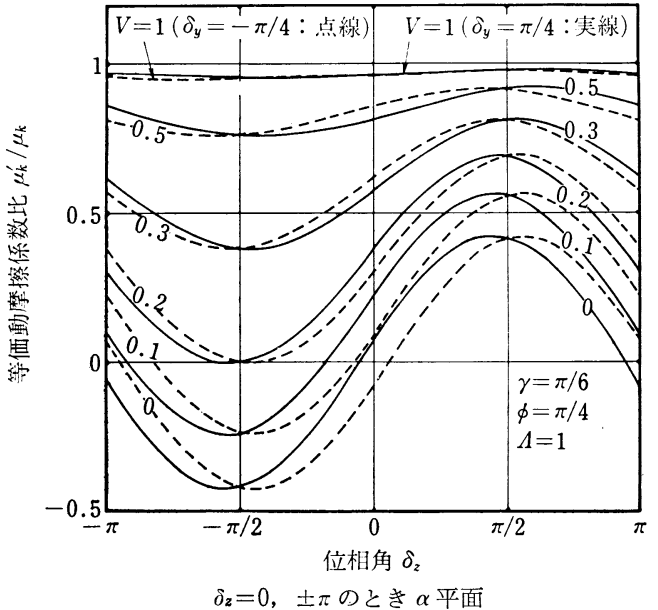

図 7 等価動摩擦係数の減少と位相角との関係（一般の 棈円振動の場合） 
ととは本質的に異なる点である．したがって，以 後このような場合,「負の等価動摩擦俰数」と呼 ぶことにする.

図 8,9,10 亿は等価動摩擦係数の減少々振動の 方向および速度比との関係の数值計算例が示され ている.これらの結果からも, $\mu_{k}^{\prime}$ の減少は $\gamma, \phi$, $V$ 飞依存するが，同一の振動方向であっても，位 相角 $\delta_{z}$ 亿著しく影響されることがわかる.

ところで, このような動摩摖の等価的な負抵抗 化汇関して, 最も有効な振動の方向は簡単な考察 の結果 (図 9,10 参照), $\phi=0$ すなわち $X-Z$ 平面 内の棈円振動の場合であることがわかる. したが って， $\phi=0$ の場合について次のような若干の解 析を行ってみることにする.

振動による動摩擦力の正負の反転は $V_{x}=0$ の ときに生じ，その時刻 $\tau_{1}, \tau_{2}$ は

$$
\left.\begin{array}{l}
\tau_{1}=\cos ^{-1}(V / \sin \gamma) \\
\tau_{2}=2 \pi-\cos ^{-1}(V / \sin \gamma)
\end{array}\right\}
$$

で表される. ただし， $V<\sin \gamma$

$$
\text { したがって, } \mu_{k}^{\prime} / \mu_{k} \text { は }
$$

$$
\frac{\mu_{k}{ }^{\prime}}{\mu_{k}}=\frac{1}{2 \pi} \int_{0}^{2 \pi} \pm\left\{1-\Lambda \cos \gamma \sin \left(\omega t+\delta_{z}\right)\right\} \mathrm{d}(\omega t)
$$

を計算することによって得られる。ここで，複号は， $0 \leqq \omega t \leqq \tau_{1}, \tau_{2} \leqq \omega t \leqq 2 \pi$ のとき $(-), \tau_{1}<\omega t<\tau_{2}$ のとき (十)を表す，その結果， $\mu_{k}^{\prime} / \mu_{k}$ は

$\frac{\mu_{k}^{\prime}}{\mu_{k}}=\frac{2}{\pi}\left[\sin ^{-1}\left(\frac{V}{\sin \gamma}\right)+\Lambda \cos \gamma \sin \left\{\cos ^{-1}\left(\frac{V}{\sin \gamma}\right)\right\} \sin \delta_{z}\right]$

で表される，そして，式(12)より $\mu_{k}^{\prime}$ が負の最大值をと りらる位相角は $\delta_{z}=-\pi / 2$ であり,$V \rightarrow 0$ とともに $\mu_{k}^{\prime}$ / $\mu_{k}$ はー $(2 / \pi) \Lambda \cos \gamma$ 飞漸近する。一方， $\mu_{k}^{\prime}$ の減少に及ぼ す振動効果の最も少ない位相角は $\delta_{z}=\pi / 2$ であり,$V \rightarrow$ 0 とともに $\mu_{k}^{\prime} / \mu_{k}$ は $(2 / \pi) A \cos \gamma$ 飞漸近する。 また, $V \geqq \sin \gamma$ のときには動摩擦力の 正負の 反転が生じなく なるから, 図 9,10 の場合には, $V \geqq 0.5 て ゙ \mu_{k}^{\prime} / \mu_{k}=1$ と なることを意味している.

以上のような考察から位相角 $\delta_{z}$ は $\mu_{k}{ }^{\prime}$ を負とする際の 重要なファクタであるが, $\alpha$ 平面内の棈円振動 $\left(\delta_{z}=0\right.$, $\pm \pi)$ が作用する場合にも， $\delta_{y}$ の範囲によっては $V \rightarrow 0$ の とき $\mu_{k}^{\prime}$ が負となりらることが数值計算の結果からもわ かっている. しかしながら， $\delta_{y}$ の影響は $\delta_{z}$ に比較して 非常に少ない.

このようと等価動摩擦係数は作用する棈円振動の形態 によってさまざまな挙動を示すが，一般に $\mu_{k}^{\prime}$ を負とし 得る条件を整理すると次のようになる.すなわち， $V \rightarrow$

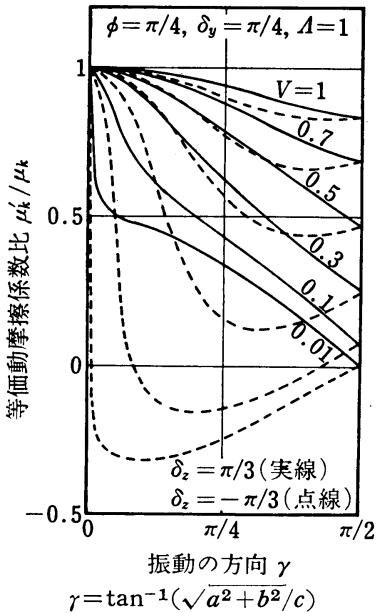

図 8 等価動摩擦係数の減少々 振動の方向との関係

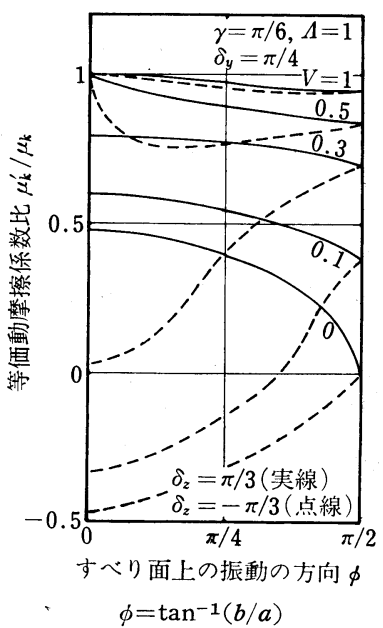

図 9 等価動摩擦係数の減少と すべり面上の振動の方向 との関係

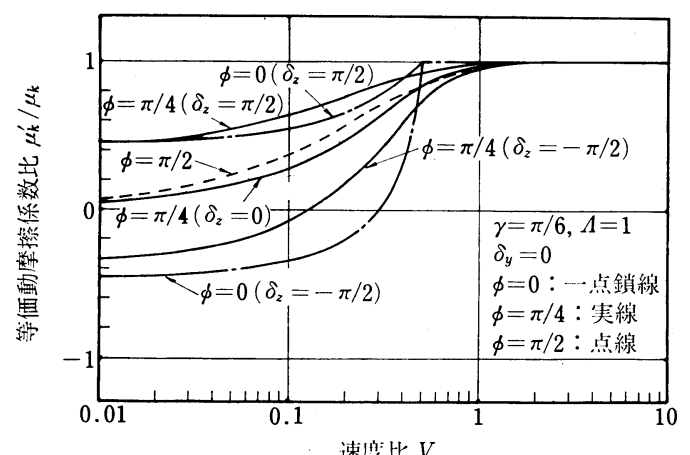

図 10 等価動摩擦係数の減少と速度比との関係 $(X-Z, \phi$, $Y-Z$ 平面内の楕円振動の場合）

0 として $0 \leqq \phi<\pi / 2$ 亿拈いて (i) $-\pi<\delta_{z}<0$, (ii) $\boldsymbol{o}_{z}=0$ のとき $-\pi / 2<\delta_{y}<0\left(\pi / 2<\delta_{y}<\pi\right), \quad \delta_{z}= \pm \pi$ のとき $0<$ $\delta_{y}<\pi / 2\left(-\pi<\delta_{y}<-\pi / 2\right)$. ᄂかしながら， $\phi=\pi / 2$ すな わち $Y-Z$ 平面内の棈円振動が作用する場合には， $X$ 方 向の振動成分が存在しないため動摩擦力の正負の反転が 生じなくなり，位相角の影響もなくなって $\mu_{k}^{\prime}$ は負とな ることはない(図 9,10 参照)。その結果, 直線振動が作 用する場合と一致する。

\section{6. 実験}

実際に際しては， $X-Y$ 平面ならびに $\phi$ 平面 $(X-Z$, $Y-Z$ 平面を含む) 内の楕円振動が作用する場合の実験が 一装置で完了するように設計製作し，以下のような一連 の実験を行った.

図 11 には， $X-Y$ 平面内の実験装置の主要部が示され 


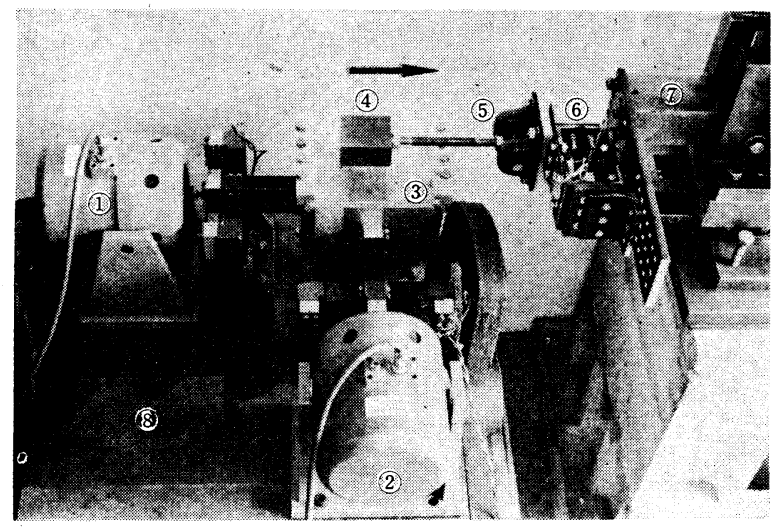

図 11 スライダによる実験装置の主要部

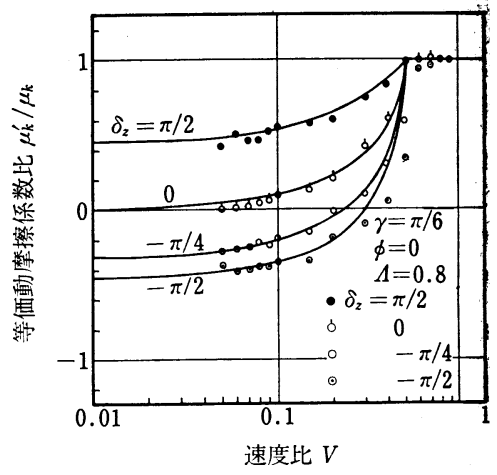

実線：理論值

図 12 等価動摩擦係数の減少実験例 $(X-Z$ 平面内の楕円振動の場合）

\section{7. 結 論}

以上の結果を要約すると次のようになる.

(1) 棈円振動の形態によって, 動摩擦力の変動は直線 振動の場合と比較してかなり異なる.

（2）法線方向成分を有しない棈円振動が作用する場合 には，Vがゼロに近づくとともに $\mu_{k}^{\prime}$ はゼロに収束 するが，直線振動の場合より $\mu_{k}^{\prime}$ の減少に及ぼす効 果は大で, $\delta_{y}= \pm \pi / 2$ が最も有効な位相角である.

（3）法線方向成分を有する棈円振動が作用する場合に は，Vがゼ口に近づいても $\mu_{k}^{\prime}$ は正あるいは負のあ る値に漸近し，ゼロには収束しない。

(4) 一般に， $\mu_{k}^{\prime}$ を負とする条件は $0 \leqq \phi<\pi / 2$ におい て， $V \rightarrow 0$ として (1)- $\pi<\delta_{z}<0$ あるいは (2) $\delta_{z}=0$ の とき $-\pi / 2<\delta_{y}<0\left(\pi / 2<\delta_{y}<\pi\right), \quad \delta_{z}= \pm \pi$ のをき $0<$ $\delta_{y}<\pi / 2\left(-\pi<\delta_{y}<-\pi / 2\right)$ の場合である.

(5) $\mu_{k}^{\prime}$ を負とする最も有効な振動の方向と位相角は $\phi=0, \delta_{z}=-\pi / 2$ であり，Vがゼロに近づくととも に, $\mu_{k}^{\prime} / \mu_{k}$ は $-(2 / \pi) \Lambda \cos \gamma$ に漸近する.

最後に，本研究に関して御指導を賜りました東京大学 名誉教授西村源六郎先生, 東京大学教授神保泰雄先生に 感謝致します。また，計算や作図等に協力された金沢工 業大学機械工学科小坂實氏に謝意を表します.

（この研究の計算は金沢工業大学電子計算機 IBM 370/ 158 によって行った.)

\section{参 考 文 献}

1) J. P. Den Hartog: Forced Vibrations with Combined Viscous and Coulomb Damping, Phil. Mag., 9, (1930) 801.

2) 清水辰次郎: 非線型振動論, 培風館 (1965) 114 .

3）例えば, D. Sinclair: Frictional Vibrations, J.Appl. Mech., (1955.6) 207.

4）横山恭男, 岡部佐規一：静摩擦係数に及ぼす振動の 影響 (第 2 報)，精密機械，33，8 (1967) 509 .

5）横山恭男, 岡部佐規一, 石川憲一：振動に上る等価動摩 擦係数の減少, 日本機械学会論文集, 36, 286 (1970) 915.

6) 岡部佐規一, 横山恭男, 神保泰雄: 振動輸送の研究（第 1 報)，精密機械， 35，5（1969） 299 .

7）石川憲一，横山恭男：振動を利用した高分子材料の精密 切断の研究, 昭和 51 年度精機学会秋季大会学術講演会前 刷 (1976) 27 . 